\title{
Nutritional and biochemical changes induced by lead in sunflower (Helianthus annuus L.)
}

\section{Distúrbios nutricionais e bioquímicos induzidos pelo chumbo em girassol (Helianthus annuus L.)}

\author{
Claudia Brito de $\mathrm{Abreu}^{1 *}$; Bárbara Lima do Sacramento²; Andréia Teixeira Alves ${ }^{3}$; \\ Silvany Cardim Moura ${ }^{2}$; Milena Santos Pinelli'; André Dias de Azevedo Neto ${ }^{5}$
}

\begin{abstract}
The aim of this study was to evaluate the effects of increasing concentrations of lead $(\mathrm{Pb})$ in the nutrient solution on growth and macronutrient and organic solute contents of Helianthus annuus plants. The experimental design was completely randomized with four replications. The dry mass yield was not affected by the treatments up to a $\mathrm{Pb}$ concentration of $0.6 \mathrm{mM}$, indicating that $H$. annuus was tolerant to this $\mathrm{Pb}$ concentration in the growth medium. The reductions in leaf, stem and root dry masses at a $\mathrm{Pb}$ concentration of $0.8 \mathrm{mM}$ were 74,84 and $85 \%$, respectively. Lead stress did not reduce the levels of nitrogen $(\mathrm{N})$, phosphorus $(\mathrm{P})$ and potassium $(\mathrm{K})$, indicating that the growth reduction observed at $0.8 \mathrm{mM}$ $\mathrm{Pb}$ could not be attributed to deficiencies of these nutrients. On the other hand, $\mathrm{Pb}$ significantly reduced calcium $(\mathrm{Ca})$ and magnesium $(\mathrm{Mg})$ contents in leaves, stems and roots, which might, at least in part, explain the $\mathrm{Pb}$-induced growth reduction in the $H$. annuus plants. $\mathrm{Pb}$ increased soluble carbohydrate, free amino acid and proline contents in leaves, and soluble protein and proline contents in roots, showing stress-induced changes in cell metabolism. The data also suggest that $\mathrm{Ca}$ and $\mathrm{Mg}$ concentrations may be used as nutritional indicators and the proline content may be used as a biochemical indicator of $\mathrm{Pb}$ toxicity in $H$. annuus.
\end{abstract}

Key words: Lead. Helianthus annuus. Mineral nutrition. Heavy metal. Organic solutes.

\section{Resumo}

Objetivou-se com esse trabalho, avaliar os efeitos de doses crescentes de chumbo $(\mathrm{Pb})$ na solução nutritiva sobre o crescimento e teores de macronutrientes e solutos orgânicos em plantas de Helianthus annuиs, em casa de vegetação. $\mathrm{O}$ delineamento experimental foi o inteiramente casualizado, com quatro repetições. A produção de massa seca não foi afetada até o tratamento de $0,6 \mathrm{mM}$ indicando que o $H$. annuus é tolerante até esta concentração de $\mathrm{Pb}$ no meio de cultivo. As reduções nas massas secas das folhas, caule e raízes foram de 74,84 e $85 \%$, respectivamente. O estresse por $\mathrm{Pb}$ não reduziu os teores de nitrogênio $(\mathrm{N})$, fósforo $(\mathrm{P})$ e potássio $(\mathrm{K})$, indicando que a redução do crescimento induzida pelo $\mathrm{Pb}$ não pode ser atribuída às deficiências destes nutrientes. Por outro lado, $\mathrm{o} \mathrm{Pb}$ reduziu significativamente os teores de cálcio $(\mathrm{Ca})$ e magnésio $(\mathrm{Mg})$ nas folhas, caule e raízes, o que pode, ao menos em parte,

${ }^{1}$ M.e em Solos e Qualidade de Ecossistemas, Universidade Federal do Recôncavo da Bahia, UFRB, Cruz das Almas, BA, Brasil. E-mail: claudia01abreu@yahoo.com.br

${ }^{2}$ Discentes do Curso de Mestrado em Solos e Qualidade de Ecossistemas, UFRB, Cruz das Almas, BA, Brasil. E-mail: barbaralimads@gmail.com; silvany_cardim@hotmail.com

3 Bióloga, UFRB, Cruz das Almas, BA, Brasil. E-mail: dea_alves106@yahoo.com.br

${ }^{4}$ Discente do Curso de Doutorado em Química, Universidade Federal da Bahia, UFBA, Salvador, BA, Brasil. E-mail: milanelly@, hotmail.com

${ }^{5}$ Prof. Associado, UFRB, Cruz das Almas, BA, Brasil. E-mail: andre@ufrb.edu.br

* Author for correspondence 
explicar a redução do crescimento induzida pelo $\mathrm{Pb}$ nas plantas de $H$. annuus. $\mathrm{O} \mathrm{Pb}$ aumentou os teores de carboidratos solúveis, aminoácidos livres e prolina nas folhas e os de proteínas solúveis e de prolina nas raízes, evidenciando as alterações no metabolismo celular decorrentes do estresse. Os dados também sugerem que os teores de $\mathrm{Ca}$ e $\mathrm{Mg}$ podem ser utilizados como indicadores nutricionais e os de prolina como indicador bioquímico da toxidez por $\mathrm{Pb}$ em $H$. annuus.

Palavras-chave: Chumbo. Helianthus annuus. Nutrição mineral. Metal pesado. Solutos orgânicos.

\section{Introduction}

Heavy metal pollution has become one of the major environmental problems worldwide (MALAR et al., 2014). It is particularly difficult to remediate soil, water and air of metal pollutants because, unlike organic pollutants, which may be degraded into harmless small molecules, toxic elements, such as lead $(\mathrm{Pb})$, mercury $(\mathrm{Hg})$, cadmium $(\mathrm{Cd})$, copper $(\mathrm{Cu})$ and zinc $(\mathrm{Zn})$, are immutable by biochemical reactions (MALAR et al., 2014). The heavy metals are defined as metals with a density higher than $5 \mathrm{~g}$ $\mathrm{cm}^{-3}$ (GASIC; KORBAN, 2006).

Excess lead in plants can cause various symptoms of toxicity, such as reduced growth, chlorosis, browning of the root system, inhibition of photosynthesis and changes in mineral nutrient concentrations (SHARMA; DUBEY, 2005). As a result of toxicity caused by the pollutant action, inhibition of cell activity or damage to the cell structure may occur due to heavy metal interference with some essential nutrients (COUTINHO; BARBOSA, 2007). Responses to stress range widely, depending on the plant species, the toxic element, and the environmental conditions (SOUZA et al., 2011).

At high soil concentrations, $\mathrm{Pb}$ replaces elements such as potassium $(\mathrm{K})$ and calcium $(\mathrm{Ca})$ in aluminosilicates, particularly feldspar, metals and sulfides (BOSSO; ENZWEILER, 2008). When soil contains large amounts of metals, their uptake by plants is mainly affected by the bioavailability fraction (VAMERALI et al., 2010). In the case of lead, the uptake occurs either in an ionic form $\left(\mathrm{Pb}^{2+}\right)$ or via a passive mechanism (KABATA-PENDIAS; PENDIAS, 2011).

Heavy metal ions are toxic to plants at the micromolar level and can induce a variety of physiological and biochemical changes, such as impairments of the membrane function, enzyme activity, hormonal balance, mineral nutrition, photosynthesis, translocation and water relations, which lead to metal-induced growth reduction (POSCHENRIEDER; BARCELÓ, 2006).

Thus, several authors have reported changes in macronutrient contents in plants grown under $\mathrm{Pb}$ stress (AKINCI et al., 2010; AUGUSTO et al., 2014; BERTOLI et al., 2011; HUANG; CUNNINGHAM, 1996; KIBRIA et al., 2009; LAMHAMDI et al., 2013; PAIVA et al., 2002, 2003) and in organic solutes in plants grown in the presence of $\mathrm{Pb}$ (BHARDWAJ et al., 2009; LAMHAMDI et al., 2013). However, little research has been conducted on the damage caused by $\mathrm{Pb}$ to physiological and biochemical processes in sunflower (Helianthus annuus L.).

H. annuus is a dicot of the family Compositae, originally from North America, which possesses important agronomic traits, such as tolerance to high and low temperatures and adaptation to different soil and climate conditions (CASTRO et al., 1997). The global production of $H$. annuus grain has grown in recent years, reaching in 2013201442.9 million tons. This is due to sunflower seed and oil characteristics, which have a number of applications in the food industry. In 2013-2014, the cultivated area for sunflower was 145,700 ha, and the production reached 232,700 tons in Brazil (CONAB, 2014). The entire plant can be used for forage, silage, and green manure (EVANGELISTA; LIMA, 2001).

Determination of heavy metals in soil, plants, and human beings, and knowledge of their toxicity are of great importance for the utilization of food and economic crops (MACÊDO; MORRIL, 2008). 
Thus, this study aimed to evaluate the effect of increasing concentrations of lead on growth and contents of macronutrients and organic solutes in $H$. annuus plants to gain a better understanding of the nutritional and biochemical effects of $\mathrm{Pb}$ on this crop.

\section{Materials and Methods}

\section{Growth and treatment conditions}

The experiment was carried out in a greenhouse of the Universidade Federal do Recôncavo da Bahia (UFRB), Cruz das Almas, Brazil, from April to May 2013.

Seeds from $H$. annuus genotype Olisun-05 were sown in 200-mL plastic cups containing washed sand and irrigated daily with distilled water. Seedlings (12-day-old) were transferred for acclimatization to trays containing $12 \mathrm{~L}$ of aerated Hoagland and Arnon (1950) nutrient solution. Treatments were applied five days later and consisted of a no-lead control and four different lead concentrations in the nutrient solution $(0.2,0.4,0.6$ or $0.8 \mathrm{mM})$, referred to thereafter as $\mathrm{Pb}_{0.0}$ through $\mathrm{Pb}_{0.8}$. Lead was applied as $\mathrm{Pb}\left(\mathrm{NO}_{3}\right)_{2}$, and each treatment contained four replicates, resulting in a total of 20 experimental plants. The experiment was performed in duplicate in order to obtain samples for biochemical and growth analyses, respectively. Lead added to the nutrient solution was chelated with EDTA to avoid precipitation with sulfate and phosphate ions. The volume of the nutrient solution was made up daily with distilled water, and the $\mathrm{pH}$ was maintained at $5.5 \pm 0.5$ by adding $\mathrm{NaOH}$ or $\mathrm{HCl}$.

After 16 days of $\mathrm{Pb}$ stress, leaf and root samples of four plants from each group were cut, frozen in liquid nitrogen, and lyophilized for further biochemical analyses. The remaining four plants were harvested, separated into leaves, stems and roots, put in paper bags and dried in an oven at $65^{\circ} \mathrm{C}$ for $72 \mathrm{~h}$ for the determination of leaf (LDM), stem (SDM) and root (RDM) dry masses using a semi- analytical balance. The dried plant material was ground to be analyzed for nitrogen $(\mathrm{N})$, phosphorus $(\mathrm{P})$, potassium $(\mathrm{K})$, calcium $(\mathrm{Ca})$, magnesium $(\mathrm{Mg})$, and lead $(\mathrm{Pb})$.

Extract preparation and nutrient and biochemical analyses

For analysis of nutrient concentrations, extracts were prepared by wet acid digestion in a mixture of concentrated sulfuric acid $\left(\mathrm{H}_{2} \mathrm{SO}_{4}\right)$ and $30 \%$ hydrogen peroxide $\left(\mathrm{H}_{2} \mathrm{O}_{2}\right)$, as described by Jones (2001). The digested samples were adjusted to a volume of $100 \mathrm{~mL}$ with deionized water to carry out the analysis of $\mathrm{N}, \mathrm{P}, \mathrm{K}, \mathrm{Ca}, \mathrm{Mg}$, and $\mathrm{Pb}$.

Determination of $\mathrm{N}$ and $\mathrm{P}$ was performed spectrophotometrically by the phenol-hypochlorite (WEATHERBURN, 1967) and molybdo-vanadate (FAITHFULL, 2002) methods, respectively. Concentrations of $\mathrm{Pb}, \mathrm{K}, \mathrm{Ca}$, and $\mathrm{Mg}$ were determined simultaneously by Inductively Coupled Plasma Optical Emission Spectrometry (ICP-OES, Varian, VISTA-PRO).

For biochemical analysis, extracts were prepared by homogenization of $1.0 \mathrm{~g}$ of lyophilized leaf and root powders with a mortar and pestle in $5 \mathrm{~mL}$ of $100 \mathrm{mM}$ potassium phosphate buffer, $\mathrm{pH} 7.0,0.1$ $\mathrm{mM}$ EDTA. The homogenate was filtered through muslin cloth and then centrifuged at $12,000 \times g$ for $15 \mathrm{~min}$. The supernatant fraction was kept in an ultra freezer $\left(-80^{\circ} \mathrm{C}\right)$ and used for the determination of organic solutes.

Soluble carbohydrates, free proline, free amino acids, and soluble proteins were determined according to the methods described by Dubois et al. (1956), Bates et al. (1973), Yemm and Cocking (1955), and Bradford (1976), respectively.

\section{Experimental design and statistical analysis}

The experimental design was completely randomized, with five treatments of four replicates 
each. The treatment effects were evaluated by analysis of variance $(p<0.05)$ and, in the case of significance, a regression study was performed using the statistical program SISVAR (FERREIRA, 2003).

\section{Results and Discussion}

\section{Growth}

The dry mass production in all parts of the $H$. annuus plants remained unchanged up to $\mathrm{a} \mathrm{Pb}$ concentration of $0.6 \mathrm{mM}$. However, it abruptly decreased in the treatment with $0.8 \mathrm{mM} \mathrm{Pb}$, and the reductions in the LDM, SDM, and RDM were 74, 84 , and $85 \%$, respectively (Table 1 ). Compared with the other plant organs, the roots showed the highest reduction in the dry mass as a result of $\mathrm{Pb}$ stress, probably because they are the only part directly exposed to the toxic metal. The reduction in root growth can affect the growth of the whole plant due to limited water and nutrient absorption (PEREIRA et al., 2013).

Table 1. Leaf (LDM), stem (SDM) and root (RDM) dry mass yields of H. annuus plants after 16 days of growth in a greenhouse with different concentrations of $\mathrm{Pb}\left(\mathrm{NO}_{3}\right)_{2}$ in the nutrient solution. The values indicate the mean of four replicates \pm SD. The values in parentheses represent the percentage of reduction relative to the control.

\begin{tabular}{clll}
\hline Levels of $\mathrm{Pb}(\mathrm{mM})$ & \multicolumn{1}{c}{ LDM } & \multicolumn{1}{c}{ SDM } & \multicolumn{1}{c}{ RDM } \\
\hline 0.0 & $3.995 \pm 0.811$ & $2.832 \pm 0.160$ & $2.443 \pm 0.463$ \\
0.2 & $3.649 \pm 0.283(9)$ & $2.599 \pm 0.150(8)$ & $1.827 \pm 0.248(25)$ \\
0.4 & $3.458 \pm 0.494(13)$ & $2.383 \pm 0.432(16)$ & $1.766 \pm 0.482(28)$ \\
0.6 & $3.647 \pm 0.221(9)$ & $2.605 \pm 0.253(8)$ & $1.965 \pm 0.116(20)$ \\
0.8 & $1.054 \pm 0.225(74)$ & $0.455 \pm 0.098(84)$ & $0.372 \pm 0.069(85)$ \\
\hline
\end{tabular}

\section{Lead concentrations}

The leaf and root $\mathrm{Pb}$ concentrations increased linearly, while in the stems they showed a quadratic relationship with the $\mathrm{Pb}$ levels in the nutrient solution (Figure 1). The $\mathrm{Pb}$ concentrations in the $H$. annuus leaves ranged from $0.067\left(\mathrm{~Pb}_{0.0}\right)$ to $5.22 \mathrm{mmol} \mathrm{g}^{-1}$ of dry weight $\left(\mathrm{DW}, \mathrm{Pb}_{0.8}\right)$. The stem concentrations varied from $0.51\left(\mathrm{~Pb}_{0.0}\right)$ to $5.55 \mathrm{mmol}$ $\mathrm{g}^{-1} \mathrm{DW}\left(\mathrm{Pb}_{0.66}\right)$, and the root concentrations ranged

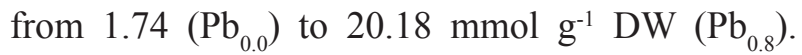
Thus, the $\mathrm{Pb}$ concentrations in the leaves and roots exposed to $0.8 \mathrm{mM} \mathrm{Pb}$ were, respectively, 76 and 11 times higher than those found in the control. In the stems, the highest $\mathrm{Pb}$ concentration was detected at a $\mathrm{Pb}$ concentration of $0.66 \mathrm{mM}$ in the solution, corresponding to a 9.78 -fold increase relative to the control. Comparison of the $\mathrm{Pb}$ contents in different parts of the plant showed that the concentrations in the roots were about three times as high as those in the stems and leaves.

Greater accumulation of $\mathrm{Pb}$ in roots than in other parts of the plant suggests that roots play an important role in the lead storage (AZAD et al., 2011). It has been shown that lead can be retained in the root cell wall, particularly in the pyrophosphate form (MARSCHNER, 2012). Lead accumulation in roots is considered to be a factor that increases plant tolerance to $\mathrm{Pb}$ toxicity, because it prevents the metal translocation to leaves (AZAD et al., 2011). In this study, it could also be observed that the stem $\mathrm{Pb}$ concentrations showed a stabilization trend, starting from the treatment with $0.2 \mathrm{mM} \mathrm{Pb}$, indicating a saturation of the $\mathrm{Pb}$ retention mechanism in the stem and, consequently, a finite capacity of this organ to act as a metal reservoir, preventing $\mathrm{Pb}$ transport to leaves. 
Figure 1. Lead $(\mathrm{Pb})$ content in leaves, stems, and roots of $H$. annuus plants after 16 days of growth in a greenhouse with different concentrations of $\mathrm{Pb}\left(\mathrm{NO}_{3}\right)_{2}$ in the nutrient solution. *Significant $(p \leq 0.05)$; ** significant $(p \leq 0.01)$.

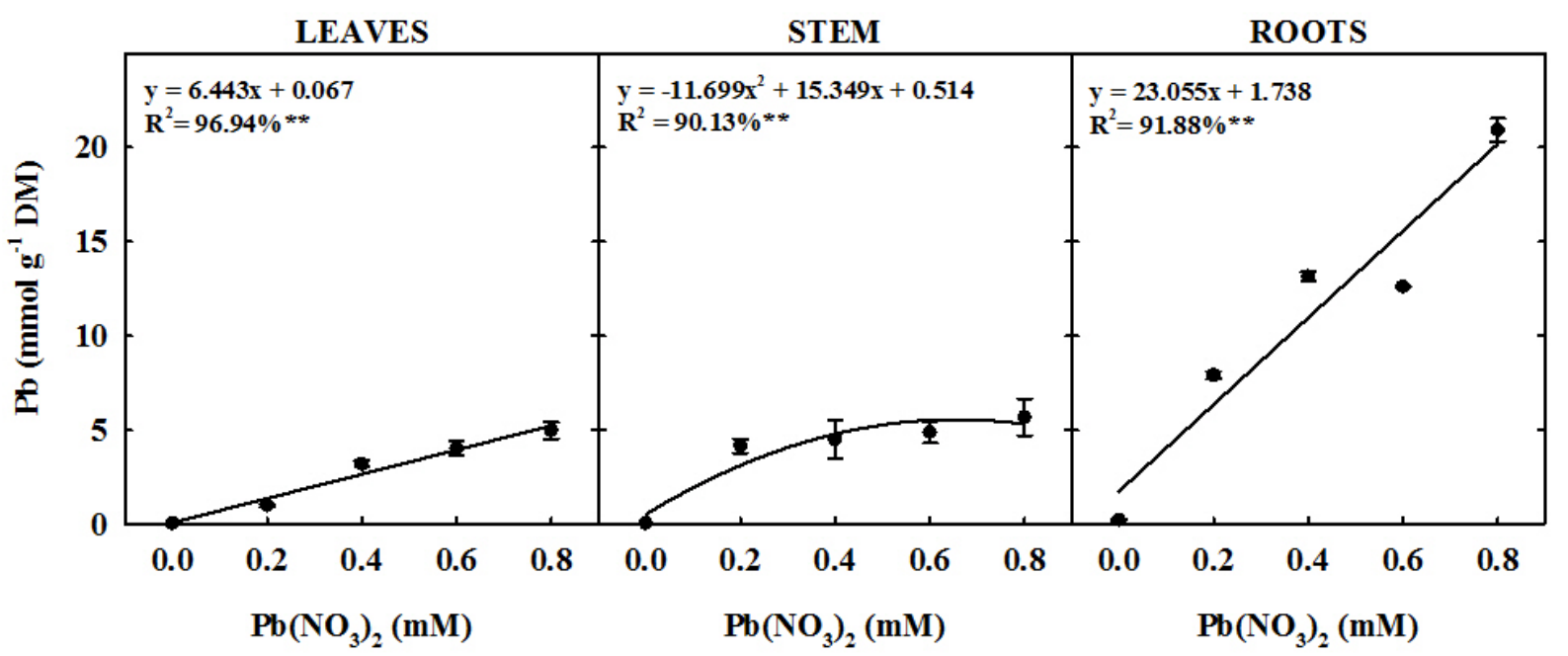

Greater $\mathrm{Pb}$ accumulation in roots compared to shoots was also reported by Romeiro et al. (2007) in Canavalia ensiformis and by Andrade et al. (2009) in Paspalum notatum. In general, apparent concentrations of $\mathrm{Pb}$ in aboveground tissues decrease as the transport distance from the root increases. This is due to a higher concentration of $\mathrm{Pb}$ in the root cell walls than in other parts of plants, showing that the transport is restricted by the root endodermis (SHARMA; DUBEY, 2005).

\section{Macronutrient (N, P, K, Ca, and $\mathrm{Mg}$ ) concentrations}

Fig. 2 shows the macronutrient (N, P and $\mathrm{K}$ ) levels in the leaves, stems, and roots of the $H$. annuus plants at different $\mathrm{Pb}$ concentrations in the nutrient solution.

It was found, using the regression equation, that $\mathrm{Pb}$ did not induce substantial changes in the $\mathrm{N}$ content in different plant parts (Figure 2). Nitrogen is a constituent of various components of the plant cell, including amino acids, nucleic acids, and chlorophylls (TAIZ; ZEIGER, 2013). It is absorbed by roots in the form of nitrate $\left(\mathrm{NO}_{3}{ }^{-}\right)$and ammonium $\left(\mathrm{NH}_{4}^{+}\right)$, with preferential uptake in the anionic form (nitrate). Considering that the $\mathrm{NO}_{3}{ }^{-} / \mathrm{NH}_{4}{ }^{+}$ratio in Hoagland solution is $14: 1$ and that $\mathrm{Pb}$ is absorbed in a cationic form, it is likely that the absence of changes in $\mathrm{N}$ concentrations observed in this study resulted from the lack of competition between this nutrient and the toxic metal. This may explain why little information is available in the literature regarding changes in $\mathrm{N}$ concentrations in plants grown in the presence of $\mathrm{Pb}$.

The leaf and stem $\mathrm{P}$ concentrations increased quadratically with the $\mathrm{Pb}$ concentration increase in the culture medium (Fig. 2). Thus, the estimated $P$ concentrations in the leaves and stems of the plants exposed to $0.8 \mathrm{mM} \mathrm{Pb}$ were, respectively, 87 and $67 \%$ higher than those in the control. This increase in the $\mathrm{P}$ concentration in shoot tissues, in conjunction with the growth reduction, indicates a concentration effect (IMO, 2012). In contrast, the mathematical simulation indicated that the $\mathrm{P}$ content in the plant roots subjected to higher $\mathrm{Pb}$ concentration decreased by only $8 \%$ (Fig. 2), suggesting that $\mathrm{Pb}$ stress did not affect the $\mathrm{P}$ translocation from roots to shoots in the $H$. annuus plants. Contrasting results were reported by (BERTOLI et al., 2011; HUANG; CUNNINGHAM, 1996; PAIVA et al., 2003), respectively, for Lycopersicon esculentum, Ambrosia artemisiifolia, and seedlings of Tabebuia impetiginosa. These authors reported that $\mathrm{Pb}$ applications increased $\mathrm{P}$ concentrations in roots. 
Figure 2. Nitrogen $(\mathrm{N})$, phosphorus $(\mathrm{P})$, and potassium $(\mathrm{K})$ contents in leaves, stems, and roots of $H$. annuus plants after 16 days of growth in a greenhouse with different concentrations of $\mathrm{Pb}\left(\mathrm{NO}_{3}\right)_{2}$ in the nutrient solution. *Significant $(p \leq 0.05) ; * *$ significant $(p \leq 0.01)$.

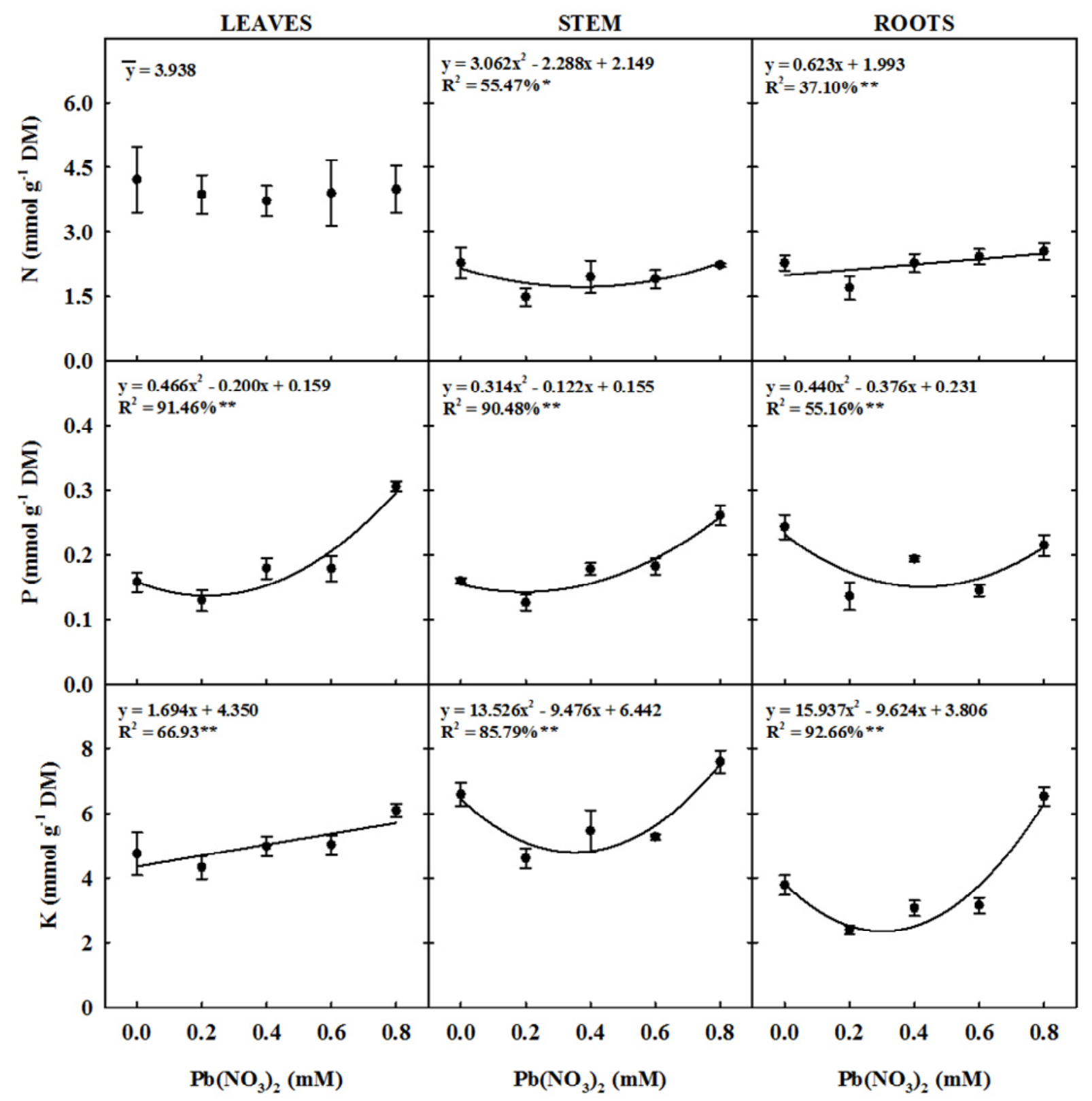

It has been suggested that increased root $\mathrm{P}$ and the $\mathrm{H}_{2} \mathrm{PO}_{4}^{-}$anions, the predominant form of $\mathrm{P}$ concentrations might be due to the formation of uptake (KABATA-PENDIAS; PENDIAS, 2001). In a $\mathrm{Pb}-\mathrm{P}$ (lead-phosphate) complex, an insoluble this study, there was no increase in the P levels in form of $\mathrm{Pb}$ unavailable for translocation from the roots, which might be due to the application of roots to shoots (HUANG; CUNNINGHAM, 1996). $\mathrm{Pb}$ chelated with EDTA to avoid metal precipitation Formation of this complex is expected due to the with $\mathrm{P}$ in the form of the $\mathrm{Pb}-\mathrm{P}$ complex. tendency of the reaction between the $\mathrm{Pb}^{2+}$ cations 
The stress caused by $0.8 \mathrm{mM} \mathrm{Pb}$ significantly increased the $\mathrm{K}$ content in all parts of the $H$. annuus plants; however, this effect was more pronounced in the roots. In the leaves, the increase was linear, while quadratic patterns were observed in both stems and roots (Figure 2). Thus, the equations indicated that in the treatment with $0.8 \mathrm{mM} \mathrm{Pb}$ the $\mathrm{K}$ content increased by 31,17 and $65 \%$ in the leaves, stems and roots, respectively, compared to the control. The data from this study indicated that the increases in the potassium concentration were the result of a concentration effect (IMO, 2012), when taking into account the significant growth reduction in this treatment. Increases in the $\mathrm{K}$ content in two Amaranthus genotypes grown in the presence of high $\mathrm{Pb}$ concentrations were also reported by Kibria et al. (2009).

Considering that $\mathrm{Pb}$ stress did not affect the uptake and translocation of $\mathrm{N}, \mathrm{P}$, and $\mathrm{K}$, the data from this study indicated that the $\mathrm{Pb}$-induced growth reduction in the $0.8 \mathrm{mM} \mathrm{Pb}$ treatment could not be due to the changes in concentrations of these elements in different plants parts.

In Figure 3, it can be observed that the $\mathrm{Ca}$ concentrations in different plant parts did not change up to a $\mathrm{Pb}$ concentration of $0.6 \mathrm{mM}$. However, the $\mathrm{Ca}$ concentrations were reduced by 21 and $28 \%$ in the leaves and stems, respectively, of the plants treated with $0.8 \mathrm{mM} \mathrm{Pb}$, showing a negative quadratic effect.

In Zea mays, Huang and Cunningham (1996) observed that $20 \mu \mathrm{M} \mathrm{Pb}$ reduced Ca concentrations by $12 \%$ in roots and more than $40 \%$ in shoots. However, no changes were observed in the $\mathrm{Ca}$ content of Ambrosia . artemisiifolia (HUANG; CUNNINGHAM, 1996). The application of $288 \mu \mathrm{M}$ $\mathrm{Pb}$ decreased by 35.6 and $18.2 \%$, respectively, $\mathrm{Ca}$ concentrations in roots and leaves of Cedrela fissilis seedlings (PAIVA et al., 2002), but did not affect levels of this nutrient in roots and stems of Tabebuia impetiginosa seedlings (PAIVA et al., 2003). Azad et al. (2011) observed that $\mathrm{Pb}$ stress decreased the $\mathrm{Ca}$ content in leaves of $H$. annuus seedlings. Augusto et al. (2014) reported that $\mathrm{Ca}$ contents in roots and leaves of Brassica juncea were significantly affected at lower Pb levels. Małkowski et al. (2005) found that a higher absorption of $\mathrm{Ca}$ occurred with increasing $\mathrm{Pb}$ accumulation in root tips of Zea mays.

According to Marschner (2012), divalent cations, such as $\mathrm{Pb}$, can compete with other cations, such as $\mathrm{Ca}$. The $\mathrm{Pb}$ inhibition of the $\mathrm{Ca}$ channel can be the result of either the Pb-blockage of the channel or competitive transport of these cations through the channel (MARSCHNER, 2012; SHARMA; DUBEY, 2005). Regardless of the cause, the data from this study indicated that in $H$. annuus the deleterious effect of $\mathrm{Pb}$ on $\mathrm{Ca}$ nutrition only occurred at $\mathrm{Pb}$ concentrations equal to or greater than $0.6 \mathrm{mM}$.

Calcium is a key element for maintaining cell integrity, because as a divalent ion $\mathrm{Ca}$ can form intramolecular complexes and bind molecules to form intermolecular complexes (PILBEAM; MORLEY, 2007). Pb-induced Ca deficiency may cause disturbances in cell division and elongation processes (SHARMA; DUBEY, 2005). Calcium is required for the formation of the mitotic spindle during cell division and for synthesis of the new cell wall in newly divided cells. It is also necessary for the physical integrity and normal function of membranes and, more recently, has been considered as a second messenger for various plant responses to hormonal and environmental signals (HOPKINS; HÜNER, 2009; TAIZ; ZEIGER, 2013). The data from this study suggested that reduced calcium levels could, at least partly, explain the $\mathrm{Pb}$-induced growth reduction in the H. annuus plants. 
Figure 3. Calcium $(\mathrm{Ca})$ and magnesium $(\mathrm{Mg})$ contents in leaves, stems, and roots of H. annuus plants after 16 days of growth in a greenhouse with different concentrations of $\mathrm{Pb}\left(\mathrm{NO}_{3}\right)_{2}$ in the nutrient solution. *Significant $(p \leq 0.05)$; **significant $(p \leq 0.01)$.

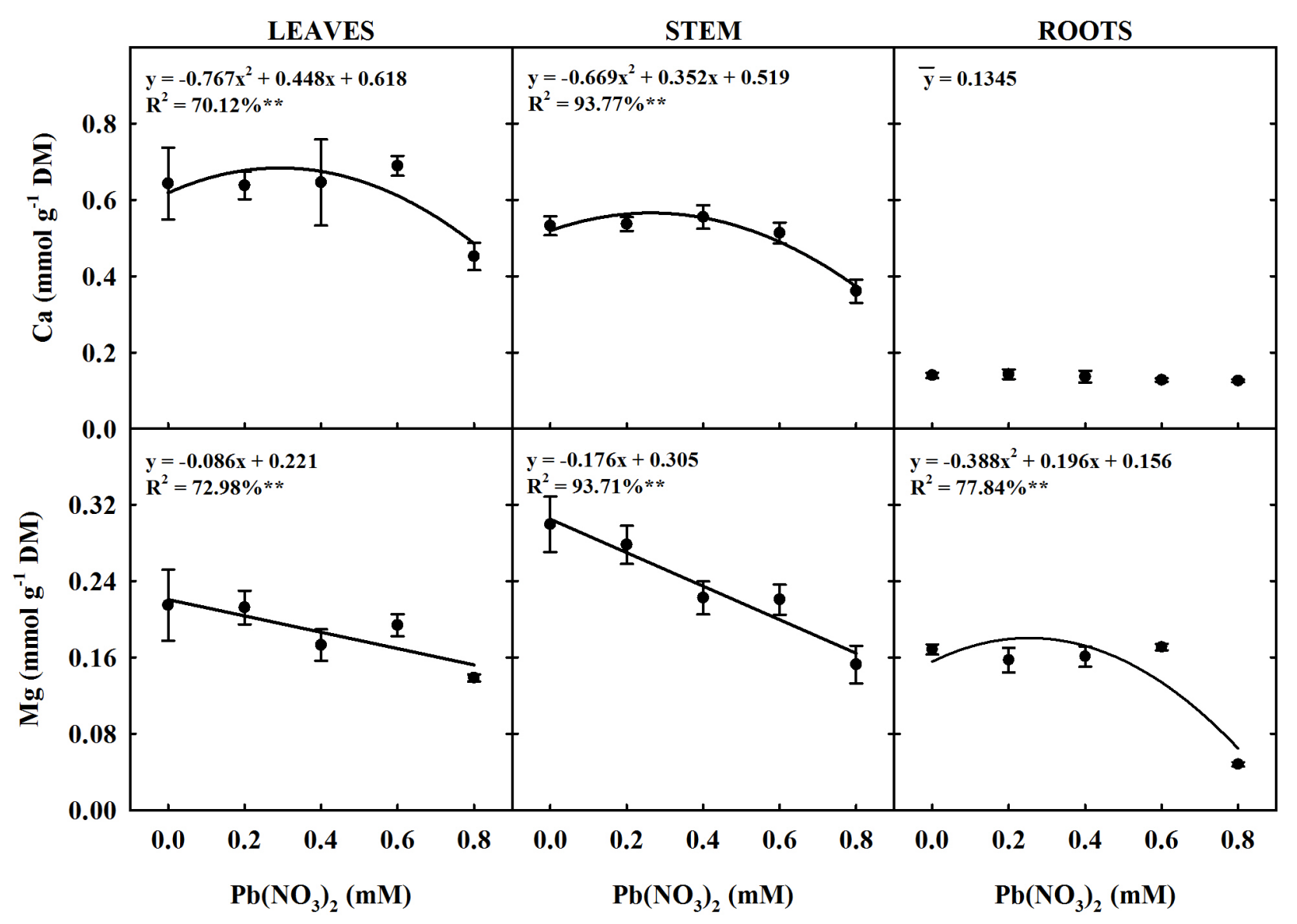

A linear negative effect of increasing $\mathrm{Pb}$ concentrations was also observed on the $\mathrm{Mg}$ contents in the leaves and stems; thereby, the levels of $\mathrm{Mg}$ were, respectively, 31 and $46 \%$ lower at $0.8 \mathrm{mM} \mathrm{Pb}$ than those in the control (Fig. 3). In the roots, the $\mathrm{Mg}$ contents showed a negative quadratic behavior and decreased dramatically (by 58\%) only in the $0.8 \mathrm{mM}$ $\mathrm{Pb}$ treatment. This reduction in the $\mathrm{Mg}$ levels could be related to a reduction in the levels of chlorophyll a and $\mathrm{b}$, observed in several species grown in the presence of $\mathrm{Pb}$ (GOMES et al., 2014).

Similar to this study, treatment with $\mathrm{Pb}$ concentrations below $0.3 \mathrm{mM}$ did not affect the $\mathrm{Mg}$ content in the roots of $T$. impetiginosa seedlings (PAIVA et al., 2003). Huang and Cunningham (1996) observed that $\mathrm{Pb}$ reduced $\mathrm{Mg}$ concentrations in shoots of Z. mays and A. artemisiifolia plants. Lamhamdi et al. (2013) reported that $\mathrm{Pb}$ concentrations higher than $1.5 \mathrm{mM}$ significantly decreased $\mathrm{Mg}$ contents in shoots and roots of Triticum aestivum and Spinacia oleracea seedlings.

In plant cells, $\mathrm{Mg}$ ions have a specific role of activating a number of enzymes involved in respiration, photosynthesis and DNA and RNA synthesis (TAIZ; ZEIGER, 2013). In addition, they have a structural role in the chlorophyll molecule, stabilization of proteins, ribosomes, nucleic acids and membranes and are critical in the reactions involving ATP (HOPKINS; HÜNER, 2009). Since $\mathrm{Mg}$ is an integral component of chlorophyll and enzyme processes of energy metabolism, its deficiency directly affects the carbon assimilation 
and energy transformations (MERHAUT, 2007). Considering that both growth and $\mathrm{Mg}$ contents were affected by $\mathrm{Pb}$ present in the culture medium, the reduction in the $\mathrm{Mg}$ content in all plant parts indicated an antagonistic effect between $\mathrm{Mg}$ and $\mathrm{Pb}$ at the absorption sites (IMO, 2012). Thus, it is likely that the reduction in the levels of this nutrient is an important factor affecting the metabolism of $H$. annuus plants and, consequently, reducing their growth.

\section{Organic solutes}

Changes in the soluble carbohydrate, free amino acid, soluble protein and free proline levels in the leaves and roots are shown in Figure 4.

In the leaves, the soluble carbohydrate levels showed a positive quadratic response and increase by $42 \%$ at the $0.8 \mathrm{mM} \mathrm{Pb}$ level. In the roots, no effect of $\mathrm{Pb}$ was observed on the levels of these compounds. Free amino acids increased linearly in the leaves and decreased linearly in the roots. Therefore, at $0.8 \mathrm{mM} \mathrm{Pb}$ the equations indicated an increase (by 76\%) of amino acids in the leaves and a reduction (by 28\%) of amino acids in the roots. The soluble protein levels showed a quadratic behavior in the leaves and decreased by $42 \%$ at $0.8 \mathrm{mM} \mathrm{Pb}$, in contrast with the roots where $\mathrm{Pb}$ stress induced a linear, about 10-fold, increase compared to the control. The free proline contents quadratically increased in the leaves and roots. Thus, the proline concentrations in the leaves and roots were, respectively, 80 and 1.5 times higher at a $\mathrm{Pb}$ concentration of $0.8 \mathrm{mM}$ than those in the control.

Several studies have reported reduction of water content in plants grown under lead stress (PATRA et al., 2004; SHARMA; DUBEY, 2005). In this scenario, an exposure to potentially toxic metal ions induces an osmotic adjustment, mainly due to accumulation of soluble carbohydrates (CHAI et al., 2012; ELLOUMI et al., 2014) and free amino acids (BHARDWAJ et al., 2009). In this work, the stressinduced increases in leaf soluble carbohydrate, free amino acid and proline contents suggested an osmotic adjustment resulting from a decrease in water availability induced by $\mathrm{Pb}$ stress. In contrast, the observation that the levels of these solutes in the roots did not increase may indicate limited water absorption by the roots and its flux to the shoots, affecting the water balance in the $\mathrm{Pb}$-stressed plants.

The increase in the leaf amino acid content also suggested a detoxification mechanism through $\mathrm{Pb}$ chelation by these compounds. Chelating agents contribute to detoxification and increase plant tolerance to toxic levels of metal ions (GASIC; KORBAN, 2006), and it is already well established that amino acids can be mobilized in response to $\mathrm{Pb}$ toxicity to form complexes with this metal (MAESTRI et al., 2010; MANARA, 2012; POURRUT et al., 2011).

The observation that the increase in leaf amino acids occurred simultaneously with the decrease in leaf soluble protein suggested the occurrence of $\mathrm{Pb}$-induced proteolysis. Bhardwaj et al. (2009) also reported that increases of $\mathrm{Pb}$ and $\mathrm{Cd}$ decreased soluble protein concentrations in leaves of Phaseolus vulgaris. On the other hand, the increase in root soluble protein occurred in parallel with the decrease in root amino acids, suggesting that protein synthesis was increased in the roots. Considering that roots are directly exposed to the contaminant, it is likely that this increase is the result of the induction of stress proteins (LAMHAMDI et al., 2010). In this context, metallothioneins and phytochelatins represent the main classes of heavy metal-chelating peptides in plants (MANARA, 2012; POURRUT et al., 2011). Pb stress has also been shown to increase the protein content, including phytochelatins, in Ceratophyllum demersum L. (MISHRA et al., 2006). 
Figure 4. Soluble carbohydrate, free amino acid, soluble protein, and free proline contents in leaves, stems, and roots of $H$. annuus plants after 16 days of growth in a greenhouse with different concentrations of $\mathrm{Pb}\left(\mathrm{NO}_{3}\right)_{2}$ in the nutrient solution. *Significant $(p \leq 0.05) ; * *$ significant $(p \leq 0.01)$.

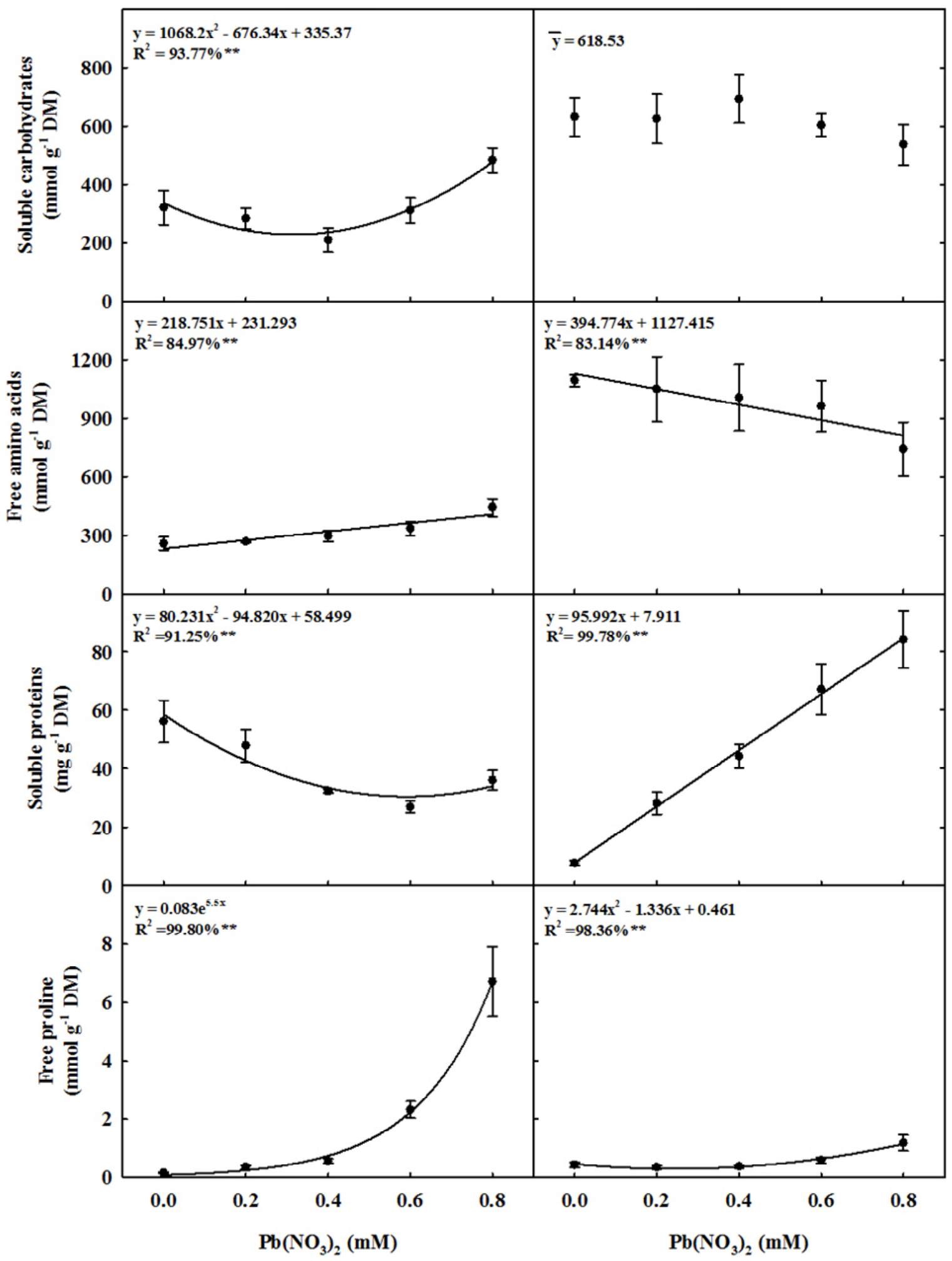


Among the organic solutes studied, the proline levels were increased most with increasing $\mathrm{Pb}$ concentrations in the nutrient solution, indicating that proline accumulation can be a good biochemical indicator of $\mathrm{Pb}$ stress in $H$. annuus. Increased proline biosynthesis has been considered to play an important role in plant tolerance to $\mathrm{Pb}$ stress (POURRUT et al., 2011; QURESHI et al., 2007; SHARMA; DUBEY, 2005). Lamhamdi et al. (2013) found that proline contents increased in leaves of T. aestivum and $S$. oleracea when the plants were exposed to increasing $\mathrm{Pb}$ concentrations. According to Verbruggen and Hermans (2008), proline contents may vary among species, and their values are up to 100 times higher in stressed plants than those in control ones. Proline accumulation is also related to stress tolerance, and concentrations of this amino acid are usually higher in tolerant than in sensitive plants (ASHRAF; FOOLAD, 2007).

There are different opinions regarding the potential mechanisms by which proline reduces the toxic effects of metals, including detoxification of excess ammonia (KAVI KISHOR et al., 2005), osmoprotection and stabilization of proteins (SHARMA; DUBEY, 2005), metal chelation (MANARA, 2012), inhibition of lipid peroxidation and removal of free radicals (WHITE, 2012). Proline can also contribute as an available source of carbon and nitrogen.

Our data showed that the presence of $\mathrm{Pb}$ in the nutrient solution significantly changed the concentrations of the major groups of cell organic solutes, indicating significant metabolic changes due to the presence of this toxic metal in the cellular environment. These changes in the metabolism may, at least in part, explain the $\mathrm{Pb}$-induced growth reduction.

\section{Conclusions}

The results of this study showed that $H$. annuus tolerates $\mathrm{Pb}$ up to a concentration of 0.6
$\mathrm{mM}$ in the culture medium and may be a viable alternative for phytoremediation programs where soil contamination with $\mathrm{Pb}$ does not exceed this limit. The data also showed that $\mathrm{Pb}$ toxicity changed the nutritional balance of $\mathrm{Ca}$ and $\mathrm{Mg}$ and the concentrations of major groups of cell organic solutes, indicating that the plant growth reduction was the result of $\mathrm{Pb}$-induced metabolic changes. Based on the results, $\mathrm{Ca}$ and $\mathrm{Mg}$ may be used as nutritional markers and proline may be used as a biochemical marker of lead toxicity in $H$. annuus.

\section{Acknowledgements}

The authors thank to Coordenacão de Aperfeiçoamento de Pessoal de Nível Superior (CAPES) and Universidade Federal do Recôncavo da Bahia (UFRB) for the financial support over the years.

\section{References}

AKINCI, I. E.; AKINCI, S.; YILMAZ, K. Response of tomato (Solanum lycopersicum L.) to lead toxicity: Growth, element uptake, chlorophyll and water content. African Journal of Agricultural Research, Lagos, v. 5, n. 6, p. 416-423, 2010.

ANDRADE, M. G.; MELO, V. F.; GABARDO, J.; SOUZA, L. C. P.; REISSMANN, C. B. Metais pesados em solos de área de mineração e metalurgia de chumbo. I - fitoextração. Revista Brasileira de Ciência do Solo, Viçosa, MG, v. 33, n. 6, p. 1879-1888, 2009.

ASHRAF, M.; FOOLAD, M. R. Roles of glycine betaine and proline in improving plant abiotic stress resistance. Environmental and Experimental Botany, Elmsford, v. 59, n. 2, p. 206-216, 2007.

Augusto, A. S.; BERTOLI, A. C.; CANNATA, M. G.; CARVALHO, R.; BASTOS, A. R. Bioacumulação de metais pesados em Brassica juncea: Relação de toxicidade com elementos essenciais. Revista Virtual de Química, Niterói, v. 6, n. 5, p. 1221-1236, 2014.

AZAD, H. N.; SHIVA, A. H.; MALEKPOUR, R. Toxic effects of lead on growth and some biochemical and ionic parameters of sunflower (Helianthus annuus L.) seedlings. Current Research Journal of Biological Sciences, Taiwan, v. 3, n. 4, p. 398-403, 2011. 
BATES, L. S.; WALDREN, R. P.; TEARE, I. D. Rapid determination of free proline for water-stress studies. Plant and Soil, Hague, v. 39, n. 1, p. 205-207, 1973.

BERTOLI, A. C.; CARVALHO, R.; CANNATA, M. G.; BASTOS, A. R. R.; AUGUSTO, A. S. Toxidez do chumbo no teor e translocação de nutrientes em tomateiro. Revista Biotemas, Florianópolis, v. 24, n. 4, p. 7-15, 2011.

BHARDWAJ, P.; CHATURVEDI, A. K.; PRASAD, P. Effect of enhanced lead and cadmium in soil on physiological and biochemical attributes of Phaseolus vulgaris L. Nature and Science, New York, v. 7, n. 8, p. 63-75, 2009.

BOSSO, S. T.; ENZWEILER, J. Ensaios para determinar o (Bio) disponibilidade de $\mathrm{Pb}$ em solos contaminados. Química Nova, São Paulo, v. 31, n. 2, p. 394-400, 2008.

BRADFORD, M. M. A rapid and sensitive method for the quantification of microgram quantities of protein utilizing the principle of protein-dye binding. Analytical Biochemistry, San Diego, v. 72, n. 1-2, p. 248-254, 1976.

CASTRO, C.; CASTIGLIONI, V. B. R.; BALLA, A.; LEITE, R. M. B. V. C.; KARAM, D.; MELLO, H. C.; GUEDES, L. C. A.; FARIAS, J. R. B. A cultura do girassol. Londrina: EMBRAPA, CNPSo, 1997. 38 p. (Circular técnica, 13).

CHAI, M. W.; LI, R. I.; SHI, F. C.; LIU, F. C.; PAN, X.; CAO, D.; WEN, X. Effects of cadmium stress on growth, metal accumulation and organic acids of Spartina alterniflora Loisel. African Journal of Biotechnology, Nairobi, v. 11, n. 22, p. 6091-6099, 2012.

COMPANHIA NACIONAL DE ABASTECIMENTO CONAB. Levantamentos de safra. Brasília: Conab, 2014. Disponível em: $<$ http://www.conab.gov.br $>$. Acesso em: 4 mar. 2015.

COUTINHO, H. D.; BARBOSA, A. R. Fitorremediação: considerações gerais e características de utilização. Silva Lusitana, Portugal, v. 15, n. 1, p. 103-117, 2007.

DUBOIS, M.; GILLES, K. A.; HAMILTON, J. K.; REBERS, P. A.; SMITH, F. Colorimetric method for determination of sugars and related substances. Analytical Chemistry, Washington, v. 28, n. 3, p. 350-356, 1956.

ELLOUMI, N.; ZOUARI, M.; CHAARI, L.; JOMNI, C.; ROUINA, B. B.; ABDALLAH, F. B. Ecophysiological responses of almond (Prunus dulcis) seedlings to cadmium stress. Biologia, Bratislava, v. 69, n. 5, p. 604609, 2014.

EVANGELISTA, A. R.; LIMA, J. A. Utilização de silagem de girassol na alimentação animal. In: SIMPÓSIO SOBRE PRODUÇÃO E UTILIZAÇÃO DE
FORRAGENS CONSERVADAS, 1., 2001, Maringá. Anais... Maringá: UEM/CCA/DZO, 2001. p. 177-217.

FAITHFULL, N. T. Methods in agricultural chemical analysis: a practical handbook. Wallingford: CABI Publishing, 2002. 262 p.

FERREIRA, D. F. SISVAR 4.6 sistema de análises estatísticas. Lavras: UFLA, 2003. 32 p.

GASIC, K.; KORBAN, S. S. Heavy metal stress. In: RAO, K. V. M.; RAGHAVENDRA, A. S.; REDDY, K. J. (Ed.). Physiology and molecular biology of stress tolerance in plants. Dordrecht: Springer, 2006. p. 219254.

GOMES, S. M. S.; LIMA, V. L. A.; SOUZA, A. P.; NASCIMENTO, J. J. V. R.; NASCIMENTO, E. S. Cloroplast pigments as indicators of lead stress. Engenharia Agrícola, Jaboticabal, v. 34, n. 5, p. 877-884, 2014.

HOAGLAND, D. R.; ARNON, D. I. The water-culture method for growing plants without soil. California Agricultural of Experimental Station Bull, California, v. 347, n. 1, p. 1-32, 1950.

HOPKINS, W. G.; HÜNER, N. P. A. Introduction to plant physiology. $4^{\text {th }}$ ed. Hoboken: John Wiley \& Sons Inc., 2009. 503 p.

HUANG, J. W.; CUNNINGHAM, S. D. Lead phytoextraction: species variation in lead uptake and translocation. New Phytologist, Lancaster, v. 134, n. 1, p. 75-84, 1996.

IMO, M. Analysis of nutritional interactions in cropping systems. In: SHARMA, P. A.; ABROL, V. (Ed.). Crop production technologies. Rijeka: InTech, 2012. p. 221242.

JONES, J. B. Laboratory guide for conducting soil tests and plant analysis. Boca Raton: Printed in the United States of America, CRC Press, 2001. 384 p.

KABATA-PENDIAS, A.; PENDIAS, H. Trace elements in soils and plants. $3^{\text {th }}$ ed. Flórida: CRC Press, 2001. 413 p.

Trace elements in soils and plants. $4^{\text {th }}$ ed. Boca Raton: CRC Press. Teylor and Francis Group, 2011. 505 p.

KAVI KISHOR, P. B.; SANGAM, S.; AMRUTHA, R. N.; SRI LAXMI, P.; NAIDU, K. R.; RAO, K. R. S. S.; RAO, S.; REDDY, K. J.; THERIAPPAN, P.; SREENIVASULU, N. Regulation of proline biosynthesis, degradation, uptake and transport in higher plants: Its implications in plant growth and abiotic stress tolerance. Current Science, Bangalore, v. 88, n. 3, p. 424-438, 2005. 
KIBRIA, M. G.; ISLAM, M.; OSMAN, K. T. Effects of lead on growth and mineral nutrition of Amaranthus gangeticus L. and Amaranthus oleracea L. Soil \& Environment, Faisalabad, v. 28, n. 1, p. 1-6, 2009.

LAMHAMDI, M.; BAKRIM, A.; AARAB, A.; LAFONT, R.; SAYAH, F. A comparison of lead toxicity using physiological and enzymatic parameters on spinach (Spinacia oleracea) and wheat (Triticum aestivum) growth. Moroccan Journal of Biology, Tétouan, v. 6, n. 7, p. 64-73, 2010.

LAMHAMDI, M.; GALIOU, O. E. L.; BAKRIM, A.; NÓVOA-MUÑ̃Z, J. C.; ARIAS-ESTÉVES, M.; AARAB, A.; LAFONT, R. Effect of lead stress on mineral content and growth of wheat (Triticum aestivum) and spinach (Spinacia oleracea) seedlings. Saudi Journal of Biological Sciences, Riyadh, v. 20, n. 1, p. 29-36, 2013.

MACÊDO, L. S.; MORRIL, W. B. B. Origem e comportamento dos metais fitotóxicos: revisão de literatura. Tecnologia \& Ciência Agropecuária, João Pessoa, v. 2, n. 2, p. 29-38, 2008.

MAESTRI, E.; MARMIROLI, M.; VISIOLI, G.; MARMIROLI, N. Metal tolerance and hyperaccumulation: costs and trade-offs between traits and environment. Environmental and Experimental Botany, Elmsford, v. 68, n. 1, p. 1-13, 2010.

MALAR, S.; VIKRAM, S. S.; FAVAS, P. J. C.; PERUMAL, V. Lead heavy metal toxicity induced changes on growth and antioxidative enzymes level in water hyacinths [Eichhornia crassipes (Mart.)]. Botanical Studies, Taipei, v. 55, n. 54, p. 1-11, 2014.

MAŁKOWSKI, E.; KURTYKA, R.; KITA, A.; KARCZ, W. Accumulation of $\mathrm{Pb}$ and $\mathrm{Cd}$ and its effect on $\mathrm{Ca}$ distribution in maize seedlings (Zea Mays L.). Polish Journal of Environmental Studies, Olsztyn, v. 14, n. 2, p. 203-207, 2005.

MANARA, A. Plant responses to heavy metal toxicity. In: FURINI, A. (Ed.). Plants and heavy metals. New York: Springer, 2012. p. 27-53.

MARSCHNER, P. Marschner's mineral nutrition of higher plants. $3^{\text {th }}$ ed. Londres: Academic Press, 2012. $651 \mathrm{p}$.

MERHAUT, D. J. Magnesium. In: BARKER, A. V.; PILBEAM, D. J. Handbook of plant nutrition. Boca Raton: CRC Press, 2007. p. 145-181.

MISHRA, S.; SRIVASTAVA, S.; TRIPATHI, R.; KUMAR, R.; SETH, C.; GUPTA, D. Lead detoxification by coontail (Ceratophyllum demersum L.) involves induction of phytochelatins and antioxidant system in response to its accumulation. Chemosphere, Londres, v. 65, n. 6, p. 1027-1039, 2006.
PAIVA, H. N.; CARVALHO, J. G.; SIQUEIRA, J. O. Influência da aplicação de doses crescentes de chumbo sobre o teor e o conteúdo de nutrientes em mudas de cedro (Cedrela fissilis Vell.). Scientia Forestalis, Piracicaba, n. 61, p. 40-48, 2002.

PAIVA, H. N.; CARVALHO, J. G.; SIQUEIRA, J. O.; FERNANDES, A. R.; MIRANDA, J. R. P. Influência de doses crescentes de chumbo sobre o teor e o conteúdo de nutrientes e $\mathrm{Pb}$ em mudas de ipê-roxo (Tabebuia impetiginosa (Mart.) Standl.). Revista Árvore, Viçosa, MG, v. 27, n. 2, p. 151-158, 2003.

PATRA, M.; BHOWMIK, N.; BANDOPADHYAY, B.; SHARMA, A. Comparison of mercury, lead and arsenic with respect to genotoxic effects on plant systems and the development of genetic tolerance. Environmental and Experimental Botany, Elmsford, v. 52, n. 3, p. 199-223, 2004.

PEREIRA, M. P.; PEREIRA, F. J.; RODRIGUES, L. C. A.; BARBOSA, S.; CASTRO, E. M. Fitotoxicidade do chumbo na germinação e crescimento inicial de alface em função da anatomia radicular e ciclo celular. Revista Agro@mbiente On-line, Boa Vista, v. 7, n. 1, p. 36-43, 2013.

PILBEAM, D. J.; MORLEY, P.S. Calcium. In: BARKER, A. V.; PILBEAM, D. J. Handbook of plant nutrition. Boca Raton: CRC Press, 2007. p. 121-144.

POSCHENRIEDER, C.; BARCELÓ, J. Water relations in heavy metal stressed plants. In: PRASAD, M. N. V. (Ed.). Heavy metal stress in plants: from biomolecules to ecosystems. Berlin/Heidelberg: Springer, 2006. p. 249270 .

POURRUT, B.; SHAHID, M.; DUMAT, C.; WINTERTON, P.; PINELLI, E. Lead uptake, toxicity, and detoxification in plants. Reviews of Environmental Contamination and Toxicology, New York, v. 213, p. 113-136, 2011.

QURESHI, M.; ABDIN, M.; QADIR, S.; IQBAL, M. Lead-induced oxidative stress and metabolic alterations in Cassia angustifolia Vahl. Biologia Plantarum, Praga, v. 51, n. 1, p. 121-128, 2007.

ROMEIRO, S.; LAGÔA, A. M. A.; FURLANI, P. R.; ABREU, C. A.; PEREIRA, B. F. F. Absorção de chumbo e potencial de fitorremediação de Canavalia ensiformes. Bragantia, Campinas, v. 66, n. 2, p. 327-334, 2007.

SHARMA, P.; DUBEY, R. S. Lead toxicity in plants. Brazilian Journal of Plant Physiology, Campos dos Goytacazes, v. 17, n. 1, p. 35-52, 2005. 
SOUZA, E. P. S.; SILVA, I. F.; FERREIRA, L. E. Mecanismos de tolerância a estresses por metais pesados em plantas. Revista Brasileira de Agrociência, Pelotas, v. 17, n. 2, p. 167-173, 2011.

TAIZ, L.; ZEIGER, E. Fisiologia vegetal. 5. ed. Porto Alegre: Artmed, 2013. 954 p.

VAMERALI, T.; BANDEIRA, M.; MOSCA, G. Field crops for phytoremediation of metal-contaminated land. A review. Environmental Chemistry Letters, Vitoria, v. 8, n. 1, p. 1-17, 2010.
VERBRUGGEN, N.; HERMANS, C. Proline accumulation in plants: a review. Amino Acids, Berlin, v. 35, n. 4, p. 753-759, 2008.

WEATHERBURN, M. W. Phenol-hypochlorite reaction for determination of ammonia. Analytical Chemistry, Washington, v. 39, n. 8, p. 971-974, 1967.

WHITE, P. J. Heavy metal toxicity in plants. In: SHABALA, S. (Ed.). Plant stress physiology. Oxfordshire: CAB International, 2012. p. 210-237.

YEMM, E. W.; COCKING, E. C. The determination of amino-acids with ninhydrin. Analytical Chemistry, Washington, v. 80, n. 1, p. 209-213, 1955. 